\title{
Language use and tourism in Yogyakarta The linguistic landscape of Malioboro
}

\author{
ANNA MARIETTA DA SILVA, YASSIR NASANIUS TJUNG, \\ SRI HAPSARI WIJAYANTI, AND CHRISTIANY SUWARTONO
}

\begin{abstract}
$^{1}$
The present study provides a depiction of Malioboro through the interconnected prisms of language presentation, language preferences, and sign informativeness. Seven hundred and twenty-nine public signs were examined and analysed. Although the analysis was limited to words, the survey also paid attention to language preferences and sign informativeness, wit, clarity, and visibility to both local and foreign visitors. Our findings reveal the dominance of Indonesian in the linguistic landscape (LL) of Malioboro, Yogyakarta's most famous street; 73\% of the signs were in Indonesian; indeed, all non-commercial signs use Indonesian. Only 15\% of all signs used English and fewer than 5\% of the signs contained Javanese, either in its original script or romanized. True to its principal target group, Indonesian speakers, the LL of Malioboro displays an exclusiveness and reflects the implementation of Indonesia's language policy. Our survey shows both Indonesian and English prevailing in commercial, regulatory, and infrastructural signs, most of which are informative.

KEYWORDS

Linguistic landscape; language preference; tourism; informativeness; Malioboro, Yogyakarta.
\end{abstract}

${ }^{1}$ Preliminary findings of this article have been presented at the fifteenth Asia TEFL International Conference-64th TEFLIN International Conference 2017, 14 July 2017, Yogyakarta, Indonesia, but were not published in the conference proceedings.

The authors can be reached at: anna.silva@atmajaya.ac.id (ANNA MARIETTA DA SILVA), yns@atmajaya.ac.id (YASSIR NASANIUS TJUNG), sri.hapsari@atmajaya.ac.id (SRI HAPSARI WIJAYANTI), christiany.suwartono@atmajaya.ac.id (CHRISTIANY SUWARTONO). More information about the authors can be found at the end of the article.

(C) 2021 Faculty of Humanities, Universitas Indonesia

ANNA MARIETTA DA SILVA ET AL. | DOI: 10.17510/wacana.v22i2.721. 


\section{INTRODUCTION ${ }^{2}$}

Tourism has become a major source of revenue in many countries, especially in the developing world (C.D. Ashley et al. 2007). The economic development of a country can depend on the growth of its tourism (H.J. Kim et al. 2006). Indonesia, which has attracted domestic and international tourists for decades, received around 11 million USD from the tourism sector in 2014 (Central Bureau of Statistics 2015). In 2016, around 8.7 million foreign tourists visited the country (The Ministry of Tourism 2017). Considering the significant contribution of tourism to the country's economy, the Indonesian Government pays development of its tourism industry serious consideration (The Ministry of Secretarial Affairs 2017).

In the context of tourism, language is vital to providing information to both local and foreign tourists about various aspects of destinations (M.A. Salim et al. 2012). Language functions as a medium to persuade tourists to visit particular destinations and share stories and reports about these places. More importantly, language serves as a guide during their visits, especially indicating places they have never been before. This includes searching for the right direction, finding the way to hotels, restaurants, and other places. Language is so important to tourism that the World Tourism Organization (2001) has created a system of information which covers, among other aspects, symbols for disabled people, routes, outdoor activities, warnings, and safety measures. The purpose of establishing a set of standardized public signs is to promote a sense of security and contentment among tourists. Nevertheless, the responsibility of providing clear and informative signs and symbols is also shared by the authorities in each tourist destination (A. Ikuta 2010). The use of language in tourism areas has been of interest to researchers in the field of Linguistic Landscape (hereinafter referred to as LL).

Previous studies on LL in tourism areas have called attention to the primacy of national over other languages in multilingual signs. Examples include the Algarve in Portugal (K. Torkington 2009), Mallorca, where the role of English as lingua franca is evident (A. Bruyèl-Olmedo and M. Juan-Garau 2009), Lithuania and Poland (J. Ruzaitè 2017), and in Dingle, Ireland, where the dominance of monolingualism over multilingualism has been identified (M. Moriarty 2014). In a nutshell, the preponderance of monolingual, bilingual, and multilingual signs depends on the specific localities (J. Cenoz and D. Gorter 2006; T. Huebner 2006; B. Lawrence 2012; U. Papen 2012). Therefore, an LL is also a contestation of identities (E. Ben-Rafael et al. 2006). In the shopping streets of Ljouwert (Leeuwaarden) in Friesland and Donostia in the Basque Country, for instance, monolingual signs predominate over bilingual and multilingual signs (Cenoz and Gorter 2006). Dutch and Spanish are the national language in Friesland and the Basque Country respectively and each language dominates in its respective area. Although Frisian, the local language

\footnotetext{
${ }^{2}$ We would like to express our sincere gratitude to Atma Jaya Institute of Research and Community Development for funding this research and to our two research assistants, Timi Timothy and Luthfiana Brilianti Kurniawan.
} 
of Friesland in which it is it is widely spoken, did not feature on many signs, Basque, the local language of the Basque Country, occurs quite frequently. Translated signs are uncommon in Ljouwert, because the language policy decrees that public signs should be either in Dutch or Frisian. By contrast, signs with partial translation are quite frequent in Donostia.

Similarly, L. Edelman (2010) found that monolingual signs predominate in the shopping streets of Amsterdam and Friesland. The national language, Dutch, is the most prominent in the two areas, whereas Frisian shows very limited occurrences in Friesland and none in Amsterdam. English is the second most popular language, occurring more frequently than French, German, Italian, and Spanish. Monolingual signs in Dutch are found in both commercial and non-commercial contexts. All official signs in Amsterdam are in Dutch; whereas they are in Dutch and Frisian in Friesland. Other languages occur in a few of the government signs. Translated texts, language mixing, and combination between translated and mixed signs are also present, with mixed signs (in Dutch and English) being much more popular than translated signs. Looking at the types of establishments these signs advertise, clothing shops were among the most prolific, followed by electronics and music outlets (other establishments included those selling pharmaceuticals, household goods, food, books, and assorted goods).

In the shopping streets of Lithuania and Poland, the majority of signs pertain to the commercial sector (Ruzaite 2017). Most restaurants in both areas use non-titular languages. Shop signs are commonly multilingual in the two sites. In Lithuania, souvenir and clothes shops are likely to be multilingual. Meanwhile, in Poland, the multilingual signs tend to be found on clothing and food shops. English is dominant in both Lithuania and Poland. By contrast, the LL of Athens, Greece, presents a context in which Greek is the dominant language. However, many shop signs do tend to use English and other languages, or mix them creatively with Greek (Alexander Nikolaou 2017). English has been used not as might have been thought because of the targeted readers' literacy but because of the language's connotation with various values such as modernity, wellness, and wealth. This has been suggested in earlier studies, for instance, in the LL of Brunei Darussalam (P. Coluzzi 2012), Addis Ababa (E. Lanza and H. Woldemariam 2013), South Korea (Lawrence 2012), and Timor-Leste (K.J. Taylor-Leech 2012).

In selecting their language preferences, the designers of signs make a conscious choice of which language will be displayed on the top, bottom, centre, left or right of the sign, and which font they will assign to them to ensure that the readers will absorb the indexical or symbolic message of the signs (see, for example, P. Backhaus 2006; Huebner 2006; Edelman 2010). So far, rarely have researchers investigated these preferences from the viewpoint of the readership. Certainly Bruyèl-Olmedo and Juan-Garau (2009) filled the gap by investigating what the tourists in Mallorca thought about the English signs they saw there. The surveyed tourists, especially those whose first language is English, expected to read English signs in hotels, but not at other 
locations such as beaches. This highlights the relationship between language and purpose: when tourists want to have more interaction with the places and people, they prefer to see more signs in English. On the other hand, when they intent upon enjoying their surroundings, they do not seem to be annoyed by the blunders made on English signs, so long as the message is clear.

So far, studies on the LL in Nusantara have been limited but a few have been carried out in different areas: Jakarta (A.M. da Silva 2016, 2017), Surakarta (Sartono 2018), and Malang (N. Yannuar 2018). The two LL studies in Jakarta focused on commercial and non-commercial signs, respectively. Both studies point to the dominance of Indonesian, indicating the exclusivity of the LL of Jakarta, whose principal target is unmistakably Indonesian speakers. Although English is prevalent, it is limited to establishments involved in finance, manufacturing, car repairs, and travel. Similarly, the LL of Surakarta shows the predominance of Indonesian, which is written in the default Latin script in both bilingual and multilingual signs. Nevertheless, other languages such as English and Arabic also frequently occur, depending on the locality, for example, the business area and the Arab quarter respectively (Sartono 2018). Different findings are presented in Yannuar's (2018) study on the LL of Malang which overtly champions a local dialect, Walikan. This is viewed as an example of the extent to which the inhabitants have embraced the local dialect, the majority of whose users are young people, alongside Indonesian and other regional languages. Another study worth mentioning is E. da Conceição Savio's (2015) in-depth research of the LL of Lautém, Timor-Leste. Given its former status as a province of the Republic of Indonesia, which officially became an independent country in 2002, Indonesian predominates on monolingual signs. However, the Lautém LL has also been characterized by multilingualism, revealed by the presence of Tetum, Portuguese, Fataluku, Makasai, Makalero, Indonesian, English, Spanish, Italian, French, Chinese, and Korean on public signs. Graffiti represented the most widespread signs, indicating the grassroots' literacy and fluidity of Lautém's population.

A direct comparison between the LLs of Nusantara and those in several European, Asian, and African countries is a difficult undertaking given the asymmetries in the available data. The LLs of Nusantara seem to depend heavily on the policies promulgated by the central and regional authorities but are naturally not immune to the local speakers' attitudes towards language diversity. The fact that the LLs of Jakarta and Surakarta display a predominance of Indonesian might reflect a desire to comply with the Law No. 24 Year 2009 regarding the national flag, language, coat-of-arms, and anthem. However, this does not preclude the speculation that, the farther one goes from the capital, the more likely it is that local languages or dialects might have a better chance of occurring in the LL, as demonstrated in the case of Malang. Interestingly, the multilingualism in Lautém provided evidence of the government policy as well as the willingness of local people to support the development of local languages (Da Conceição Savio 2015).

Thus far, the distribution, informativeness, and language preference on 
public signs has not attracted much attention. It is assumed that both the designers and readers of such signs are principally intent on the processes of providing, sharing, and obtaining the information needed to cater to tourists or visitors. Hence, the present study seeks to answer the following research questions: (1) How is language presented in Malioboro's LL?; (2) Which languages are preferred by tourists?; and (3) Are the available signs sufficiently informative, clear, and visible to both local and foreign tourists? The purpose of the study is to outline the LL and language identity of Malioboro Street, the most prominent shopping street in Yogyakarta and Central Java, in terms of its language use. It is hoped that the study will provide guidelines for stakeholders in tourist areas, including those in Yogyakarta, including the Office of Tourism and Creative Economy of the Provincial Government of Special Region of Yogyakarta, enlightening them about informativeness and language choice of public signs on view in Malioboro. Even more importantly, the current study demonstrates the utility of LL-related research through the Internet.

\section{METHOD}

Drawing on Cenoz and Gorter (2006), Edelman (2010), and Ruzaitè's (2017) insights on area selection, we opted for one famous shopping street: Malioboro. This street is roughly two kilometres long and is located in Yogyakarta, a city of 32.5 square kilometres (Central Bureau of Statistics Special Region of Yogyakarta Province 2014), which is itself situated in the central southern part of Java (see Map 1). Yogyakarta is divided into four districts plus the city proper (Provincial Government of Special Region of Yogyakarta 2017). The city has a long history as a tourist destination (Department of Education, Youth and Sports of Special Region of Yogyakarta 2015). On a more dubious a note, Malioboro has also enjoyed a certain notoriety as the place to go in the early morning and the afternoon to buy cheap, diverse, and unique souvenirs of Yogyakarta (see Figure 1 for Map of Malioboro Street). At these times, the pavement is crammed with street vendors (kaki lima) selling clothes, shoes, food, accessories, and many other items such as paintings, kitchenware, and traditional medicines (see Figure 1). Malioboro is one of the most popular and iconic sites in Yogyakarta, still holding its own alongside newer places such as Taman Pelangi, Upside Down World, Kalibiru, Mangunan Pine Forest, Tebing Breks, and the Umbulharjo Selfie Park. At night, the pavements are taken over by eateries at which people can buy and eat food which they consume sitting on the ground (lesehan) covered by mats of woven coconut or pandanus leaves (tikar). Music and artistic performances also enliven these nocturnal activities.

Even though new spots taking advantage of the government's support of tourism and creative economy have been created, Malioboro has not lost its attraction. This is firmly founded on its historical function as a shopping place for souvenirs from Yogyakarta and also to purchase the traditional food sold and enjoy the cultural shows performed there. In response to the tourists' enthusiasm to visit and stay in the vicinity of Malioboro, a number of hotels 
have been built on and near the street. All of the present researchers, who had visited Malioboro at least twice prior to the research, noted some recent changes had taken place: the pavements were wider and more comfortable for strolling pedestrians and had also been embellished with decorative lights, park benches. It was also home to several franchised restaurants, cafés, and convenience stores which did not exist two decades ago. Despite the fact we knew that Malioboro was a popular shopping street, we still felt the need to justify its selection for the present study. We therefore used Google Search and one famous tourism site, Trip Advisor.com, to search for the most popular commercial and shopping street in Java. Both sites showed that Malioboro had received the highest number of reviews in January 2017. We used the Internet because of the unavailability of such information from either Indonesia's Ministry of Tourism or its Central Bureau of Statistics.

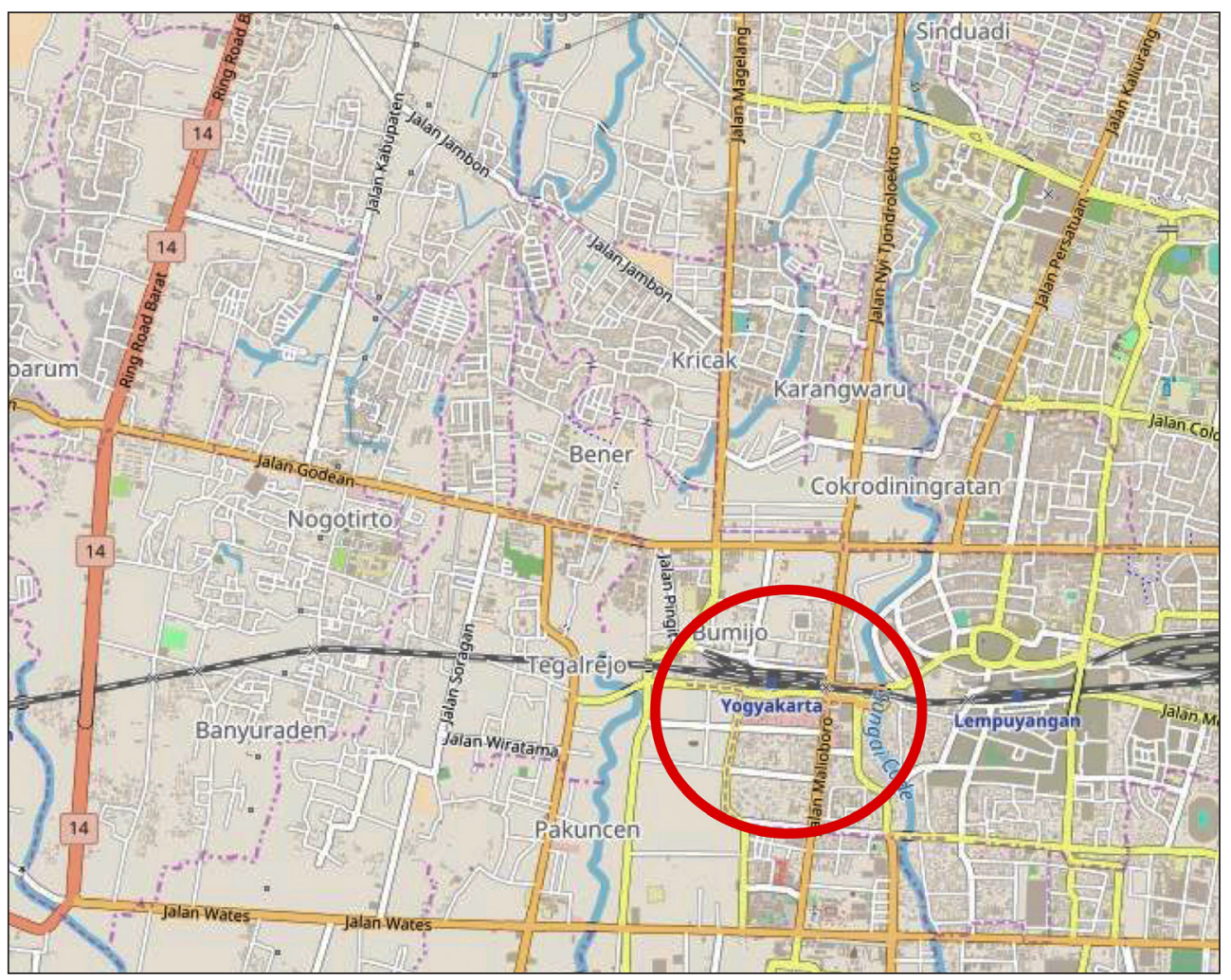

Map 1. Map of Malioboro Street. (Provincial Government of Special Region of Yogyakarta 2017). ${ }^{3}$

${ }^{3}$ Retrieved from: https://jogjaprov.go.id/, accessed on 23-11-2017. 


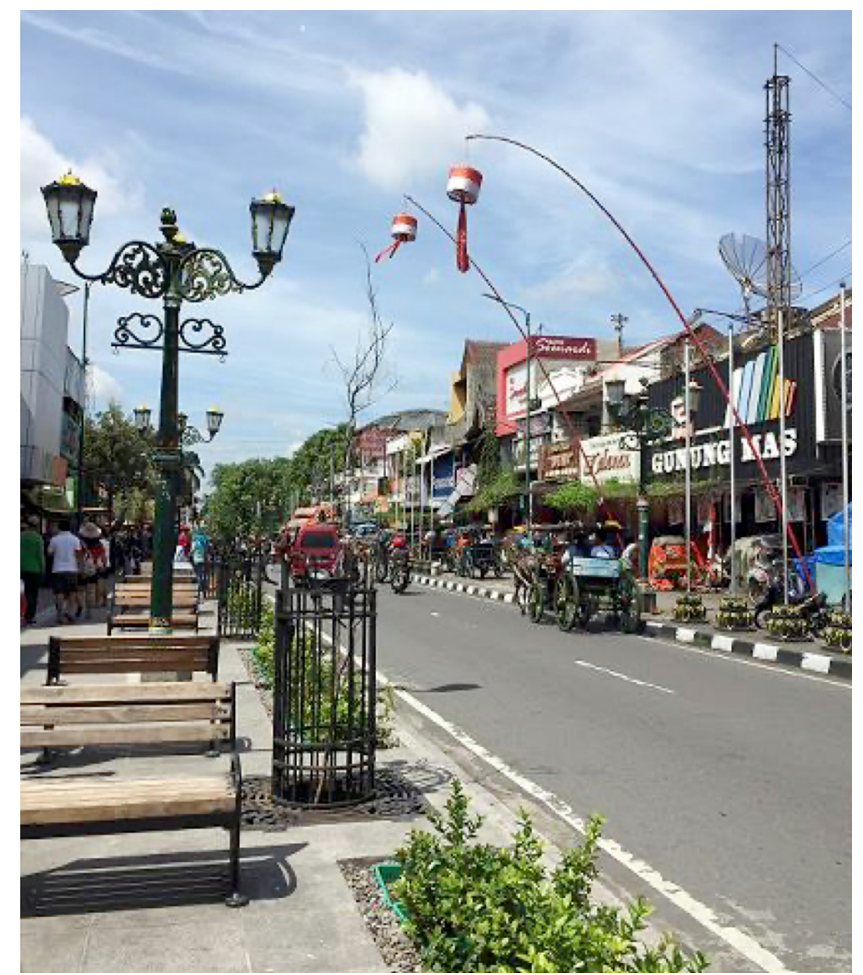

Figure 1. One side of Malioboro Street taken in March 2017. (Collection of the authors).

Data collection was carried out in March 2017. To answer our first research question about language presentation, all signs in Malioboro were photographed. We walked, made sketches of the establishments, and photographed all the signs in Malioboro using cameras, including phone cameras. It took two days to take all the photographs and make sure that no signs had been missed. Nine hundred and fifty-eight signs were collected. After excluding graffiti, proper names, illegible signs, and identical counterparts of photos already taken, we were left with seven hundred and twenty-nine signs (see Table 1). Our chosen unit of analysis was words; hence colour, images, font size, and the placement of texts or images were excluded from our analysis. The signs were classified according to R. Scollon and S.W. Scollon's (2003) typology of signs: regulatory, infrastructural, and commercial. The commercial signs were further categorized according to Da Silva's (2016) establishmentbased classification, which covers art, clothing, food and beverages, mechanics and technology, and "others". The non-commercial signs were classified into regulatory and infrastructural specimens (R. Scollon and S.W. Scollon 2003). 


\begin{tabular}{lcc}
\hline Type of signs & No. & $\mathbf{\%}$ \\
\hline Commercial signs & & \\
Art & 48 & $7 \%$ \\
Cloth & 210 & $29 \%$ \\
Food and Beverages & 112 & $15 \%$ \\
Health & 35 & $5 \%$ \\
Mechanic/Technology & 27 & $4 \%$ \\
Others & 186 & $26 \%$ \\
Non-commercial signs & & \\
Regulatory & 76 & $10 \%$ \\
Infrastructure & 35 & $5 \%$ \\
\hline Total & 729 & $100 \%$ \\
\hline
\end{tabular}

Table 1. Typology of signs in Malioboro LL.

All of the classified signs were then categorized into monolingual English (in English only - see Figure 2), monolingual Indonesian (in Indonesian only - see Figure 3), monolingual Javanese (in Javanese only), bilingual (containing Indonesian to English translations or vice-versa), bilingualized (containing Indonesian and English borrowings, mixing, or switching - see Figure 4), and "bilingualized+", adapted from Da Silva and Kwary's study on signs at Jakarta's Gambir railway station (In progress). This category encompasses signs containing Indonesian, English, and Javanese (Figure 5).

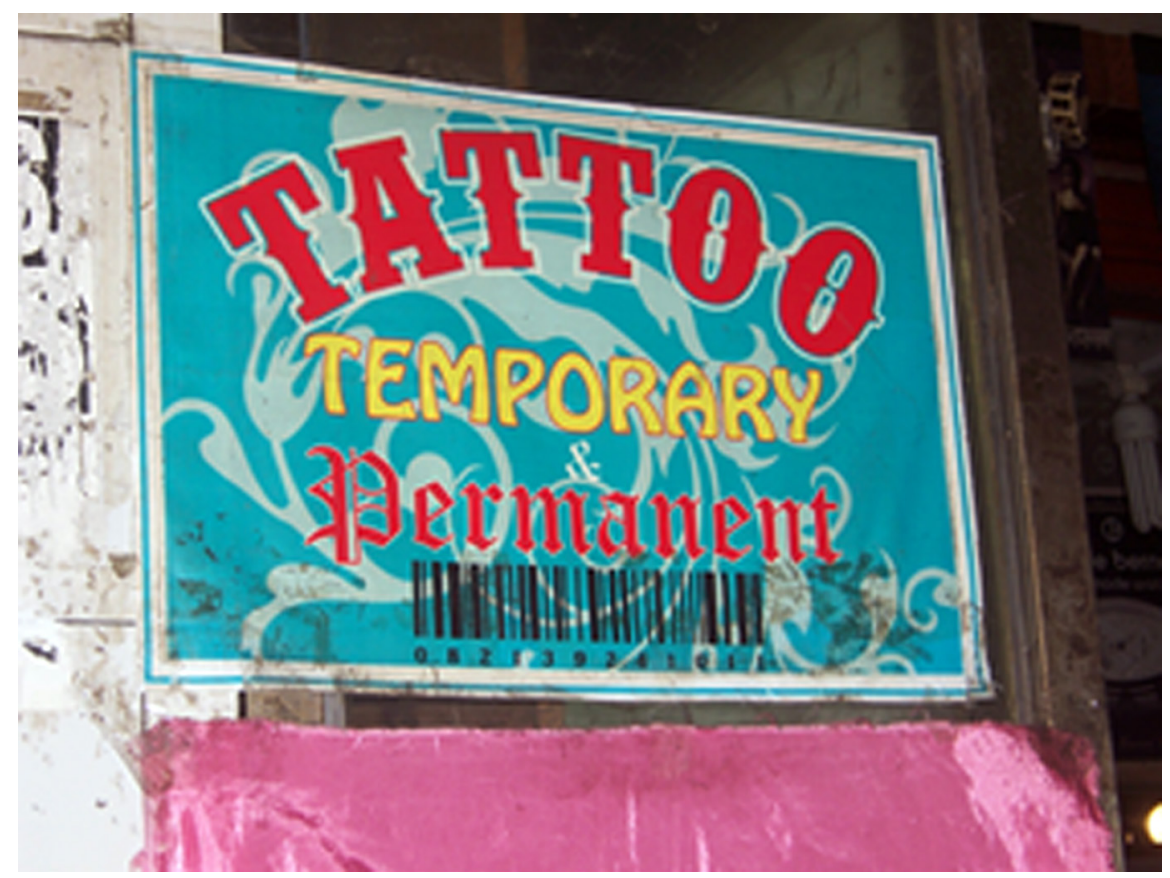

Figure 2. Sample of a monolingual English sign. (Collection of the authors). 


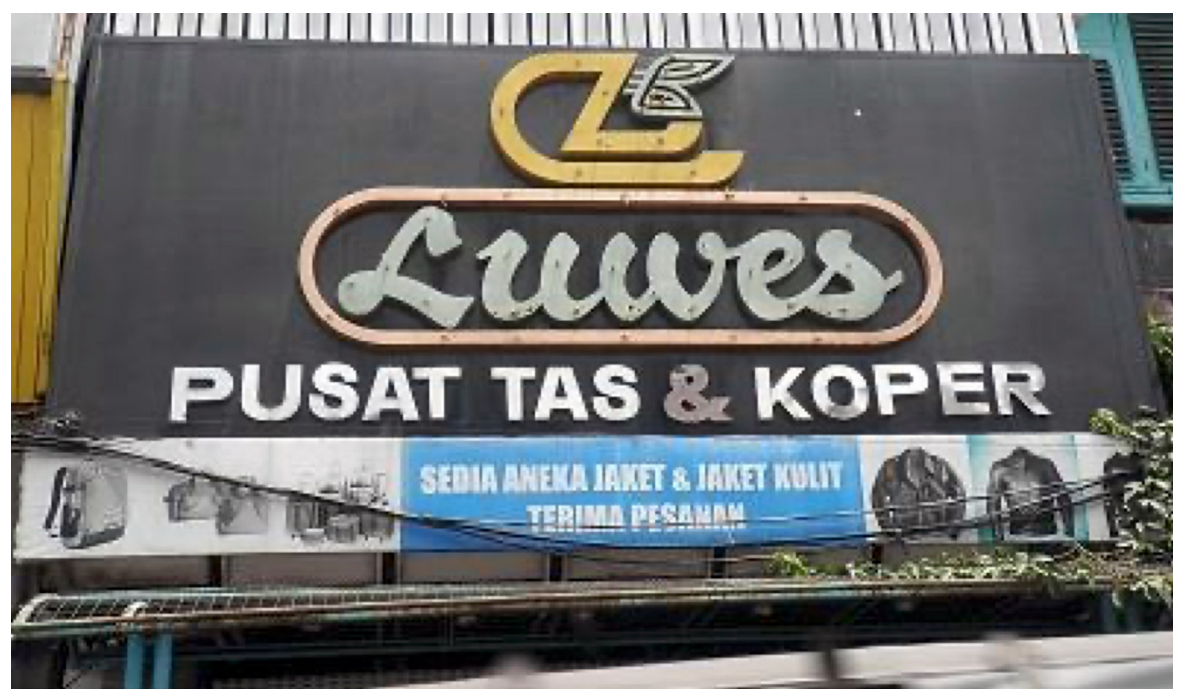

Figure 3. Sample of a monolingual Indonesian sign. (Collection of the authors).

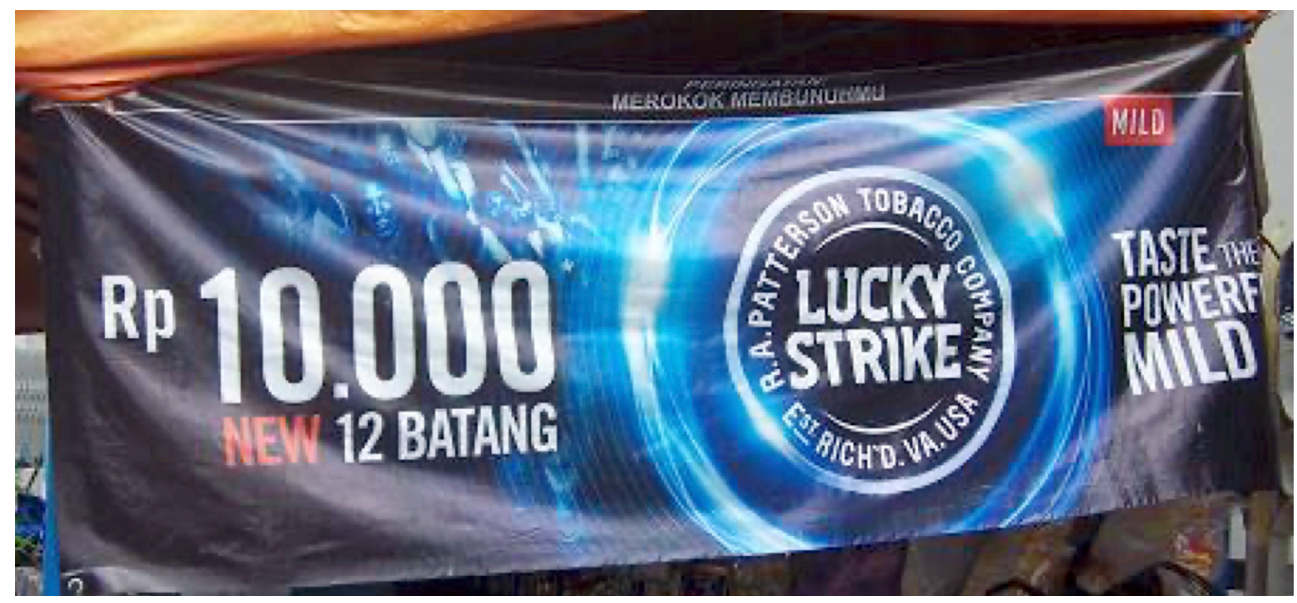

Figure 4. Sample of a bilingualized sign. (Collection of the authors).

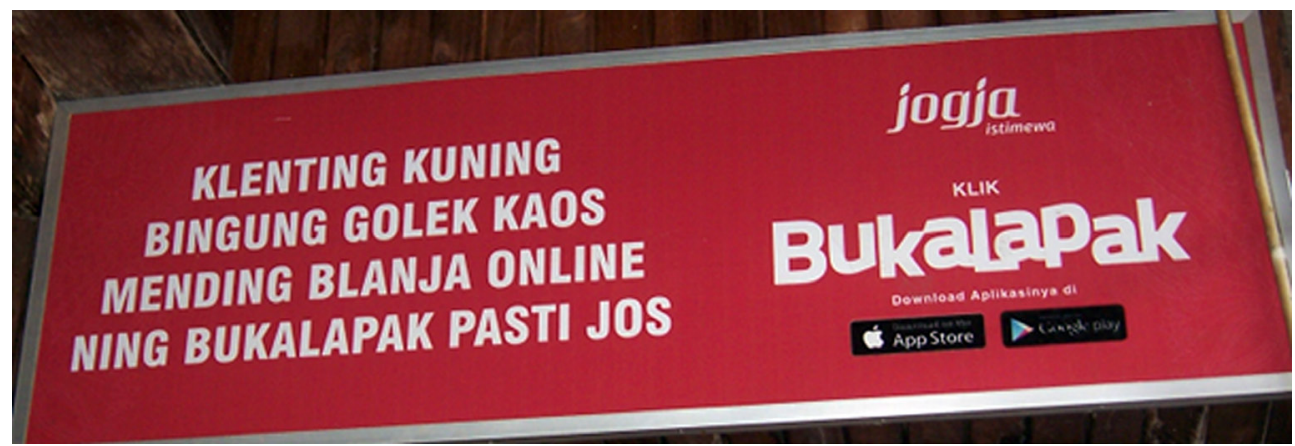

Figure 5. Sample of a bilingualized+ sign. (Collection of the authors). 
To answer our second and third research questions about language preferences and the informativeness of the signs, we conducted a survey adapted from Bruyèl-Olmedo and Juan-Garau (2009). We asked thirty-six questions about public signs, focusing on whether they were informative, clear, and visible. A descriptive statistical technique was used to analyse the answers given by the participants. The frequency of each survey question was calculated and presented in the form of tables or graphs. The questionnaires were distributed to forty respondents; 75 percent of them male and 25 percent female whose ages ranged from eighteen to seventy-five years old (Male = 31.15; Standard Deviation $=13.92$ ). Half of the respondents were Indonesians; the rest were Americans, Australians, British, Germans, Dutch, French, Hungarians, Spaniards, and Swiss (see Table 2).

\begin{tabular}{clcc}
\hline No. & Countries & Nos. & $\%$ \\
\hline 1 & America & 2 & $5 \%$ \\
2 & Australia & 3 & $8 \%$ \\
3 & England & 2 & $5 \%$ \\
4 & France & 3 & $8 \%$ \\
5 & Germany & 5 & $13 \%$ \\
6 & Hungary & 1 & $3 \%$ \\
7 & Indonesia & 20 & $50 \%$ \\
8 & Netherlands & 2 & $5 \%$ \\
9 & Spain & 1 & $3 \%$ \\
10 & Swiss & 1 & $3 \%$ \\
\hline & Total & 40 & $100 \%$ \\
\hline
\end{tabular}

Table 2. Respondents' country of origin.

Their diverse origins meant they shared varying levels of English ability, ranging from 1 (very bad) to 5 (very good). Table 3 shows that 70 percent of our respondents were able to understand English fairly well or well. Most of them had been told about Malioboro by their friends. Other sources of information included the Internet, family, guidebooks, and travel agents. The duration of their stay varied. Most respondents stayed for three days. Others choices were five, four, or two days. They rarely stayed longer than a week.

\begin{tabular}{ccc}
\hline Scales & Nos. & $\%$ \\
\hline 1 & 5 & $13 \%$ \\
2 & 4 & $10 \%$ \\
2.5 & 3 & $8 \%$ \\
3 & 11 & $28 \%$ \\
3.5 & 2 & $5 \%$ \\
4 & 8 & $20 \%$ \\
5 & 7 & $18 \%$ \\
\hline Total & 40 & $100 \%$ \\
\hline
\end{tabular}

Table 3. The respondents' English ability in 1-5 scale. 

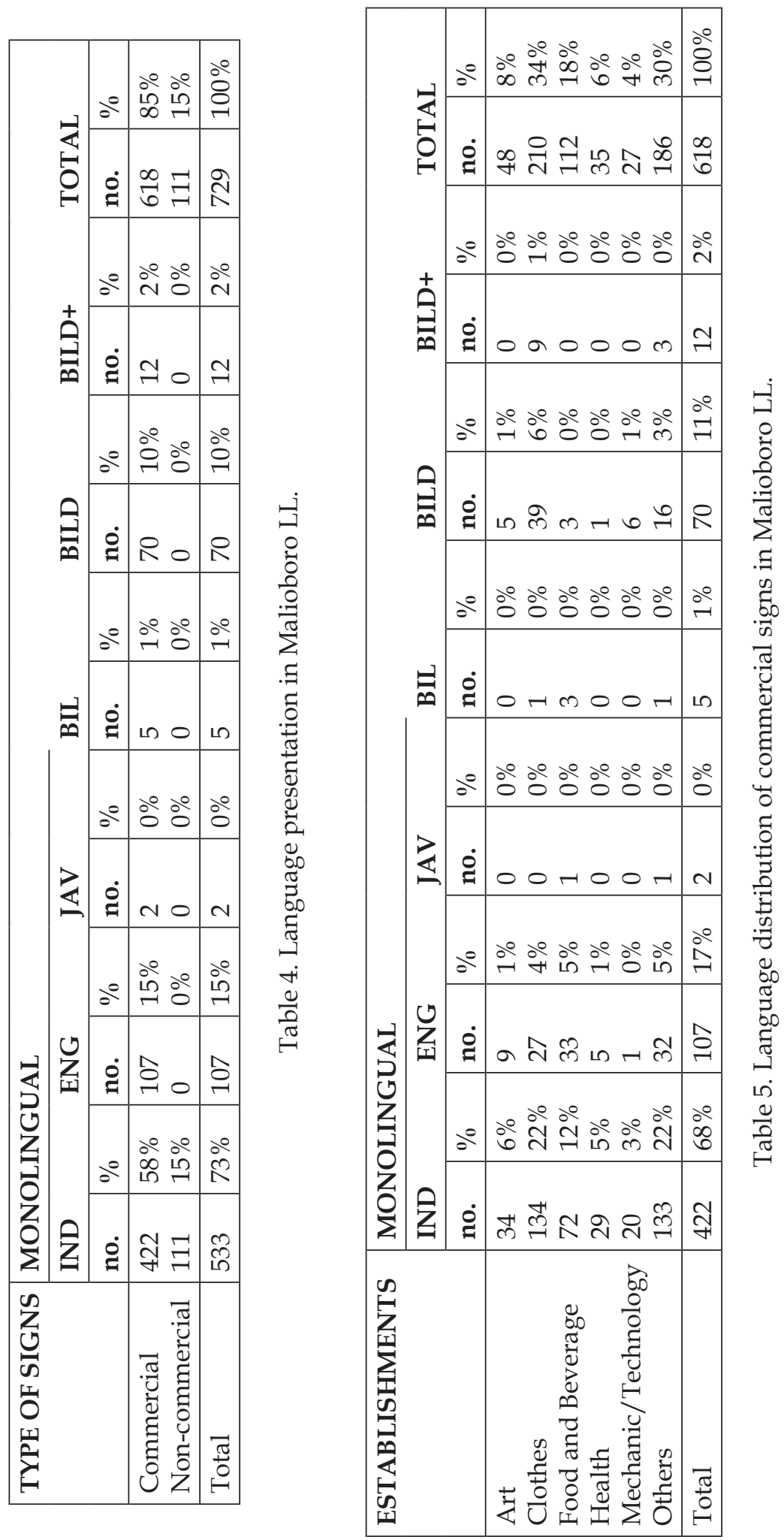


\section{FINDINGS AND DISCUSSION}

This section presents our findings on the language presentation, language preferences and the informativeness, clarity and visibility of the public signs in Malioboro.

\subsection{LANGUAGE PRESENTATION}

Most of the signs in Malioboro were commercial (85\%) as illustrated in Table 4, as ties in with the designation of Malioboro as a commercial area in Yogyakarta. Our data indicate the dominance of Indonesian for both commercial and non-commercial signs in the LL of Malioboro; 73 percent of the signs were in Indonesian. Only 15 percent of all the signs used English. Fewer than 5 percent of the signs contained romanized Javanese or Javanese script. Javanese script was used only for names of streets or particular buildings. Our data indicate that this script is not used on commercial and non-commercial signs. Romanized Javanese, however, did feature on a few commercial signs.

The predominance of Indonesian in Malioboro accords with the national policy of language use on public signs, which stipulates that Indonesian is the major language. However, local or foreign languages can be used in addition to Indonesian. Bilingual signs (containing translations) were almost zero. Our findings support those of Cenoz and Gorter (2006) and Edelman (2010) which have shown that monolingual signs in the national language prevail by virtue of language policy. However, unlike the use of Basque in the Basque country, the local Javanese language is not commonly used in Malioboro. Javanese in its original script is used only for names of streets, while romanized Javanese is used for commercial signs in combination with Indonesian and English words.

In the case of bilingual signs, our data differ from the Dutch situation (Edelman 2010) and resemble the findings relating to Basque (Cenoz and Gorter 2006); there are almost no translated signs in Malioboro. The very limited number of translated signs points to a level of exclusiveness (see Da Silva 2016), since the majority of targeted readers are Indonesian speakers. Nevertheless, Malioboro is also a tourist destination attracting numbers of foreign visitors. In the main streets in Indonesia, bilingual signs are rare; they are chiefly present in international airports and central train stations (Da Silva and Kwary In progress), because the targeted readership includes Indonesian and English speakers.

The data from different types of establishments shown in Table 5 confirms Malioboro's identity as the commercial area in which to purchase clothes and accessories. From the 618 commercial signs collected, 34 percent pertained to clothing, 30 percent to malls, department stores (whose products are related to fashion), and other miscellaneous shops, and 18 percent to food and beverages, including restaurants and outlets for food and drinks. The signs of other establishments, including in the domains of art (art galleries, jewellery shops), health (reflexology, massage services, and traditional herbal drinks), and technology and mechanics (power stations and cell phone shops) are fewer in number. Malioboro's prime identity is that of a place where visitors can find T-shirts, batik products, dresses, purses, sandals, bags, fans, Javanese headgear 
for men (blangkon), and key-holders associated with Yogyakarta. Our findings correspond to those of Edelman (2010): clothing had the highest frequency compared to other establishments.

In line with the dominance of Indonesian in Malioboro's LL, the majority of the commercial signs are written in this language (68\%). Only 17 percent of the signs is in English and fewer than 1 percent is solely in Javanese. Monolingual Indonesian signs predominate, contrasting to Edelman's (2010) observations on multilingual signs in the Netherlands. The signs of the predominant type of establishment (clothing shops) tend to be in Indonesian rather than English, Javanese, or a mixture between them. The same is seen in other establishments. The Indonesian dominance reflects Law No. 24 of 2009, which decrees a mandatory and primary use of Indonesian in public signs. However, it might also reflect the observation Malioboro is visited by more Indonesian than foreign tourists. Although the office of tourism in Malioboro did not have exact data on the number of local and foreign visitors to Malioboro, it claimed that most of the visitors to the area are domestic tourists from various regions in Indonesia. ${ }^{4}$ In the five main streets in Jakarta (Ancol Baru Selatan, Antasari, Halim Perdanakusuma, Kembangan Baru, and Prapatan), Indonesian is also dominant in commercial signs (Da Silva 2016). Unlike Amsterdam, where English is frequently used (Edelman 2010), this language does not play a significant role in Malioboro.

Signs which display a mixture of Indonesian and English comprise 11 percent of the whole. Signs mixing Indonesian, English, and (romanized) Javanese rare, unlike the prevalence of the local Basque language on public signs (Cenoz and Gorter 2006). In Malioboro, the use of Javanese seems to be symbolic, as exemplified in Figure 6. This sign contains an advertisement for an online shop consisting of a poem in which Javanese is mixed with Indonesian, Jakartan Indonesian, and English (1):

Klenting Kuning
bingung golek kaos
mending blanja online
ning bukalapak pasti jos.

This sign informs Indonesian readers that they can buy t-shirts at Bukalapak (the name of a big online shop in Indonesia). The use of Javanese conveys that the advertisement "speaks" the same language as the local Javanese speech community. The use of the local fictional character Klenting Kuning lends additional support to this symbolic meaning. ${ }^{5}$ Amusingly, the final letters /ing/ in this name rhymes with the Jakartan Indonesian word mending 'should have' and Javanese ning 'at'. Hence, this example exemplifies a technique to attract the attention of the readers (and potential buyers) by the creative use of language (Figure 6).

\footnotetext{
${ }^{4}$ Interview by S.H. Wijayanti with Darmanto (approximately 50 years), Yogyakarta, 29-3-2017.

5 This is an alias of Dewi Galuh Candra Kirana, the wife of Raden Panji Asmoro Bangun, Prince of Jenggala-Kediri Kingdom in the famous Central Javanese tale of Ande-Ande Lumut.
} 


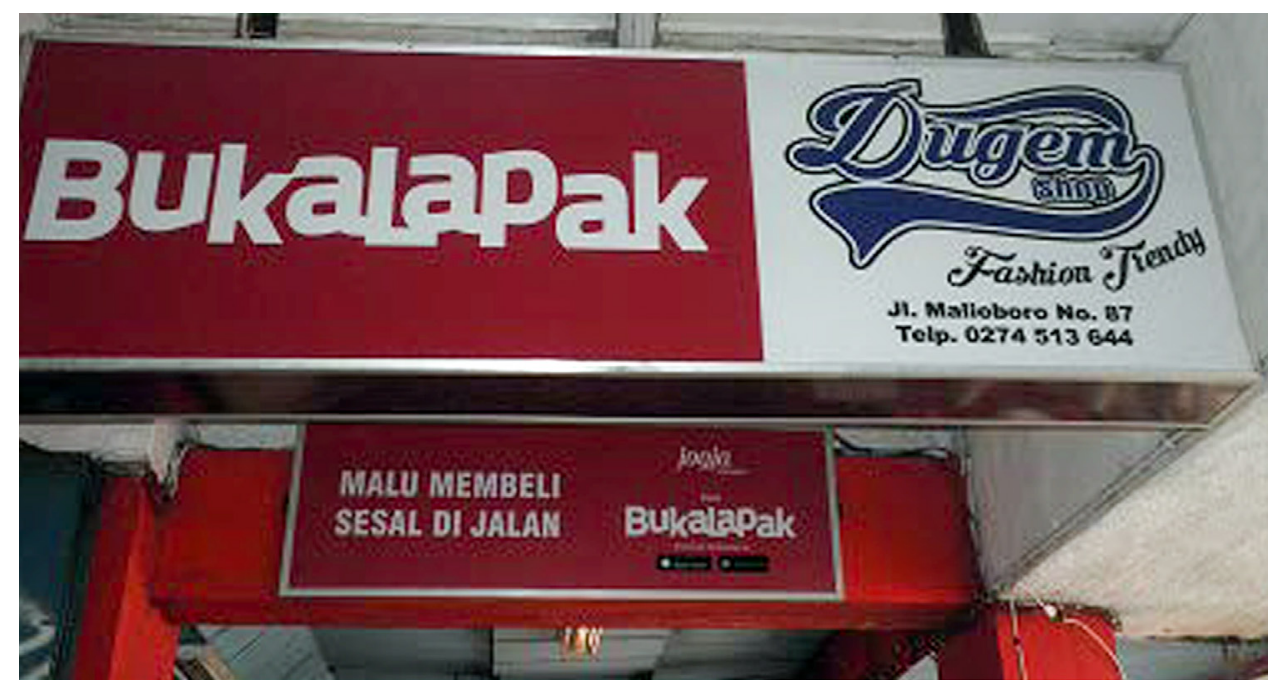

Figure 6. Sample of a sign for clothes with Indonesian and English texts. (Collection of authors).

The above sign is a Bukalapak advertisement and for the Dugem Shop (dugem means 'clubbing'). Note the tagline underneath the sign (2), which is a variant of a famous Indonesian proverb (3):

(2) Malu membeli sesal di jalan.

'[If you] shilly-shally about buying [our t-shirts], you'll regret it.'

(3) Malu bertanya sesat di jalan.

'[If you] hesitate to ask people [for directions], you'll get lost.'

This proverb is commonly passed on to newcomers to prevent them from losing their way. This modified version is a language play which keeps the harmony of the original word combination while successfully creating a new meaning: the verb bertanya 'to ask' is changed to membeli 'to buy', whereas the word-final / $\mathrm{t}$ / in sesat 'to get lost' is changed to sesal 'to regret'.

The other tagline, Fashion Trendy, underneath the name of the shop (and the use of the word shop itself) shows that English is used when the product on sale is not batik but, for instance, t-shirts, trousers, jeans, jackets, or dresses. The word fashion is often found after the name of the shop (Figure 7). This corresponds to P. Sayer's (2010) findings on the preference for English in Oaxaca, Mexico, for establishments purveying fashion.

On the other hand, Indonesian is commonly used for shop signs advertising batik (see Figure 8). Note the use of the Javanese word sarimbit, which refers to batik designed for a couple. ${ }^{6}$ Indeed, not all shops which sell batik restrict themselves to Indonesian only. Sometimes even English is used for signs of

${ }^{6}$ This consists of one piece of fabric for the woman's sarong and scarf and another for the man's shirt. 
shops selling batik, presumably because of the prestigious value attached to this language (Figure 9).

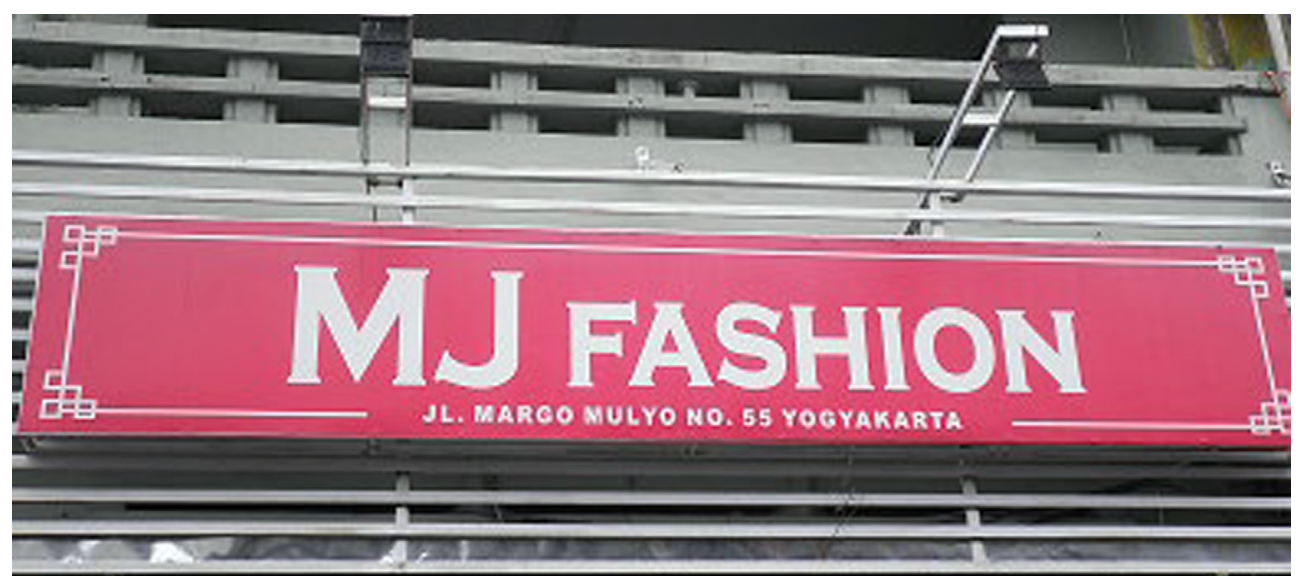

Figure 7. Sample of a sign for clothes which uses English. (Collection of authors).

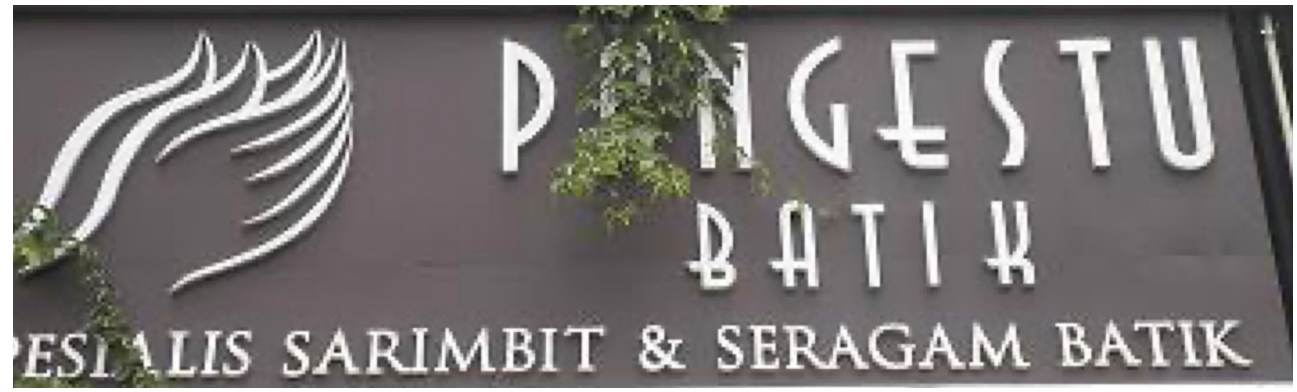

Figure 8. Sample of a sign advertising clothes with Indonesian texts and Javanese words. (Collection of authors).

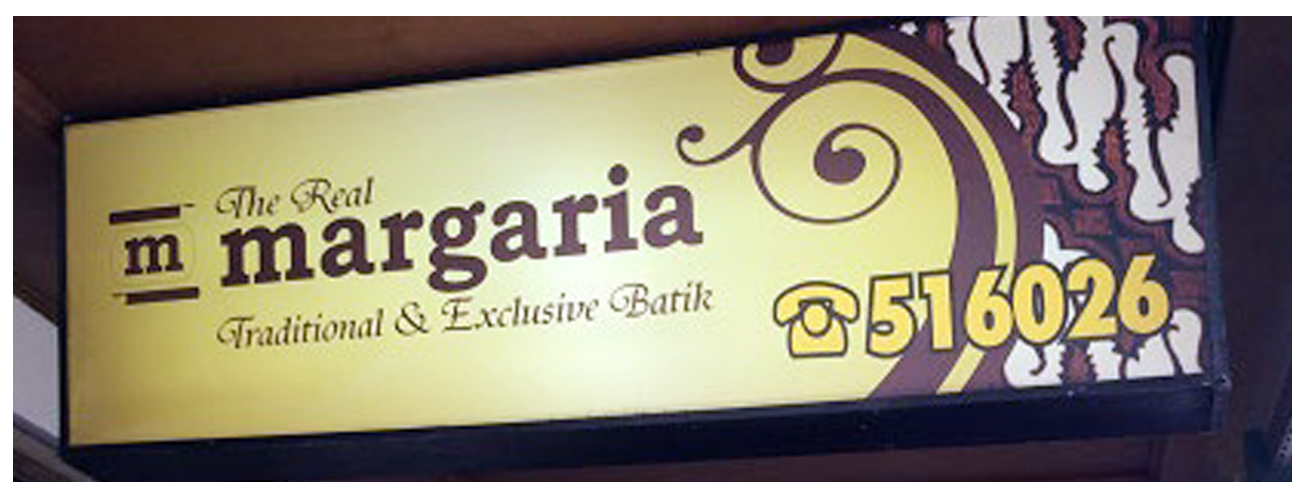

Figure 9. Sample of a sign for clothes which uses English. (Collection of authors). 
We find a similar situation in food shops and restaurants. When traditional Javanese or Indonesian food is on offered, Indonesian or Javanese is used. Popular examples include small, round sweet moon cakes filled with mung beans (bakpia; Figure 10), traditional Indonesian soup consisting of broth, meat, and vegetables and served with rice, rice-cakes, or noodles (soto), Javanese noodles (bakmi Jowo) or a traditional Yogyakartan dish made of unripe jack fruit stewed for more than one hour with palm sugar, coconut milk, and other ingredients and served with an egg, chicken, and rice (gudeg). However, when the non-traditional food is offered (for instance, donuts, burgers, and fried chicken), English is used. This seems to be related to the language policy of global establishments such as Starbucks and Dunkin' Donuts, which require the use of English (see Da Silva 2014). See Figure 11 for an example.

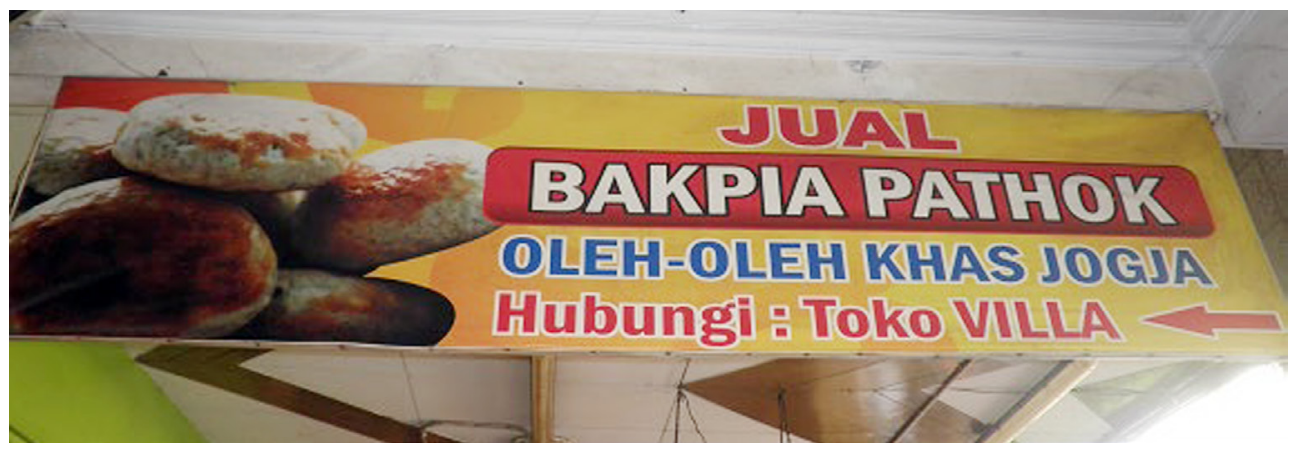

Figure 10. Sample of a sign for food which uses Indonesian. (Collection of authors).

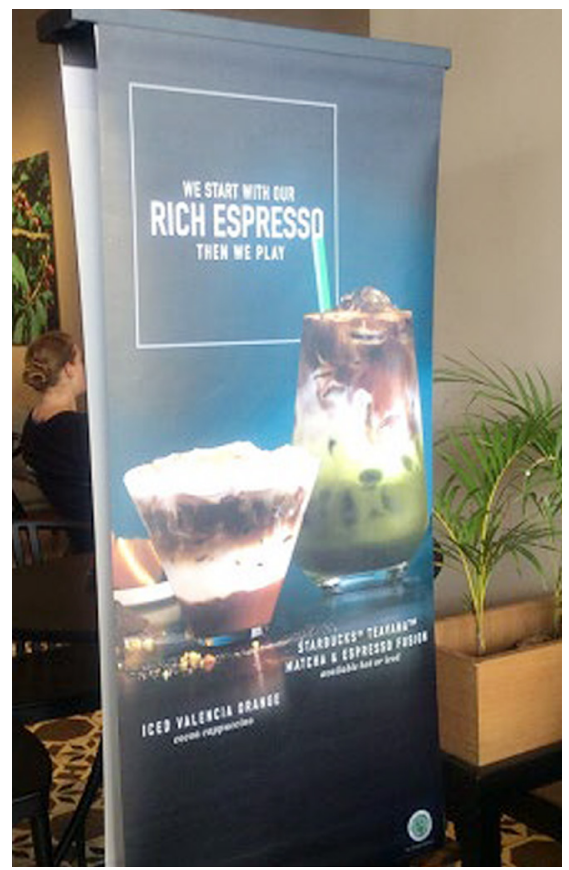

Figure 11. Sample of a sign for a beverage which uses English. (Collection of authors). 
Besides advertising clothing, signs which contain words related to technology are likely to use English or a combination of English and Indonesian (Figure 12). As the language of technology, English has been employed for signs in this domain in various LLs, for instance, in Oaxaca (Sayer 2010) and Jakarta (Da Silva 2017). Many technical terms from English have in fact become part of the Indonesian vocabulary, for instance, cyber, gadget, Internet, IT, laptop, mobile, notebook, and many more.

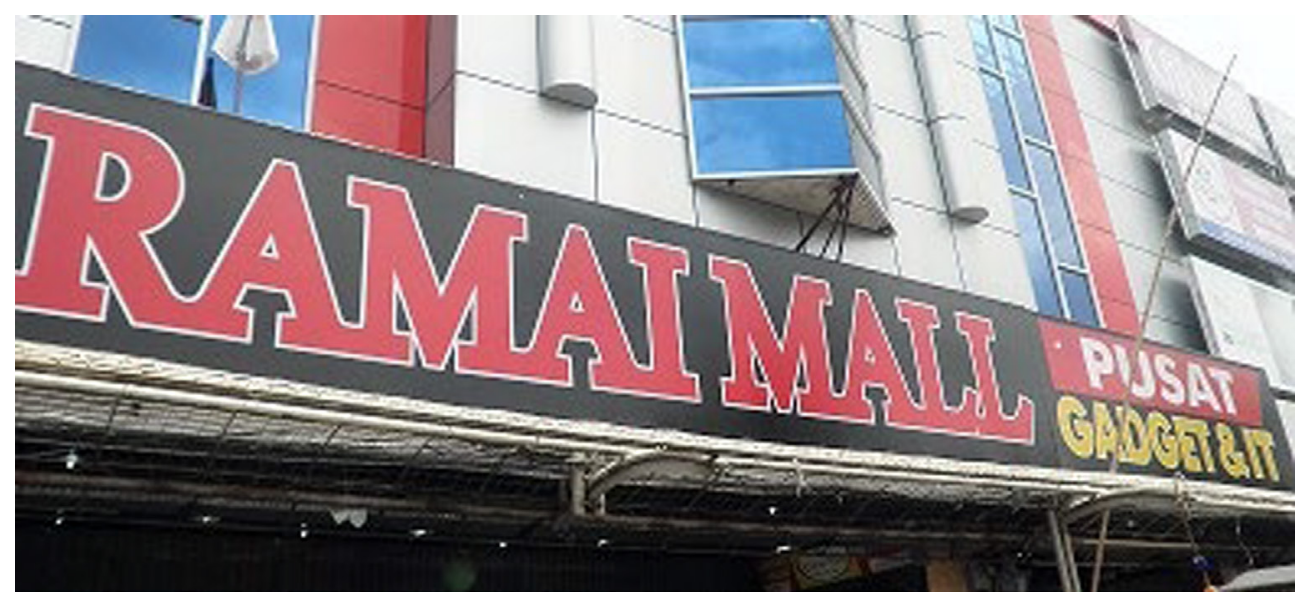

Figure 12. Sample of a sign for technology. (Collection of authors).
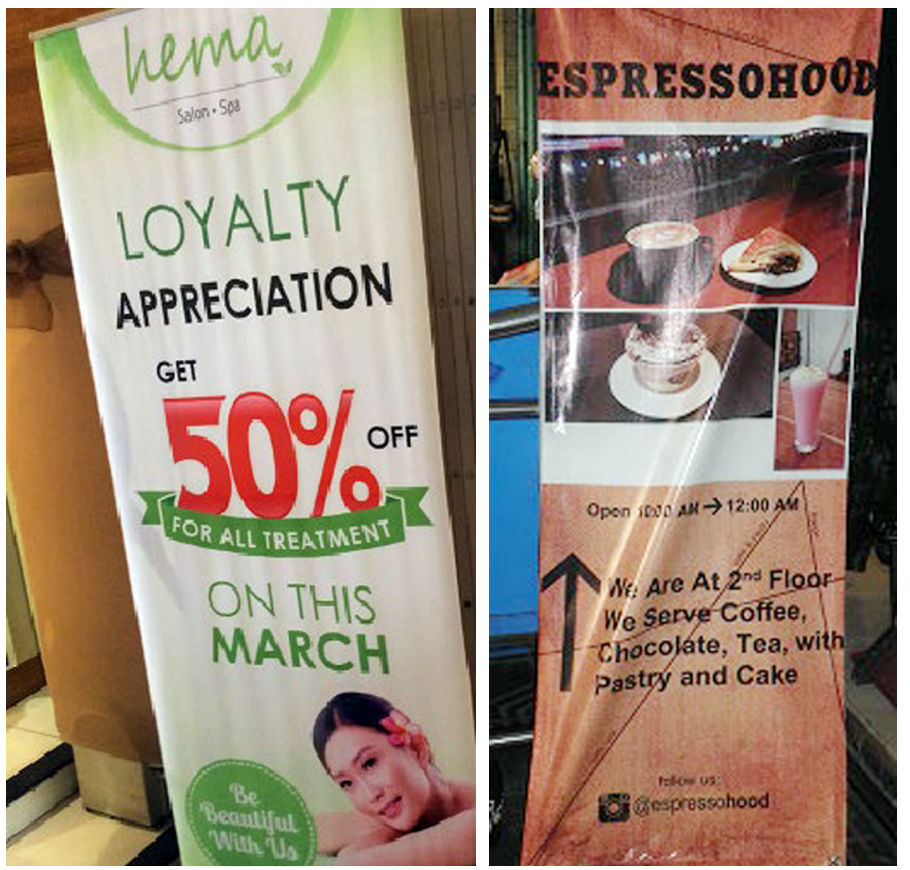

Figure 13 (left) and 14 (right). Examples of the ungrammatical use of prepositions. (Collection of authors). 
In Malioboro's LL, the signs in English do not display many idiosyncrasies compared to those on view in Tokyo (Backhaus 2006), Mallorca (BruyèlOlmedo and Juan-Garau's 2009), and Jakarta (Da Silva 2014, 2016). A small number of deviations do occur, but they are not enough to hinder English speakers' understanding of the message. One example is the misuse of the English prepositions on and at (see Figures 13 and 14 respectively).

Although proper names in Indonesian, English, and Javanese have been excluded from this study, we add a brief note that Javanese script is used in street names, underneath the corresponding roman letters (Figure 15). This differs from the use of the Javanese script in Surakarta, where it is found not only in non-commercial signs, such as the names of streets and institutions, but also for names of shops (Sartono 2018).

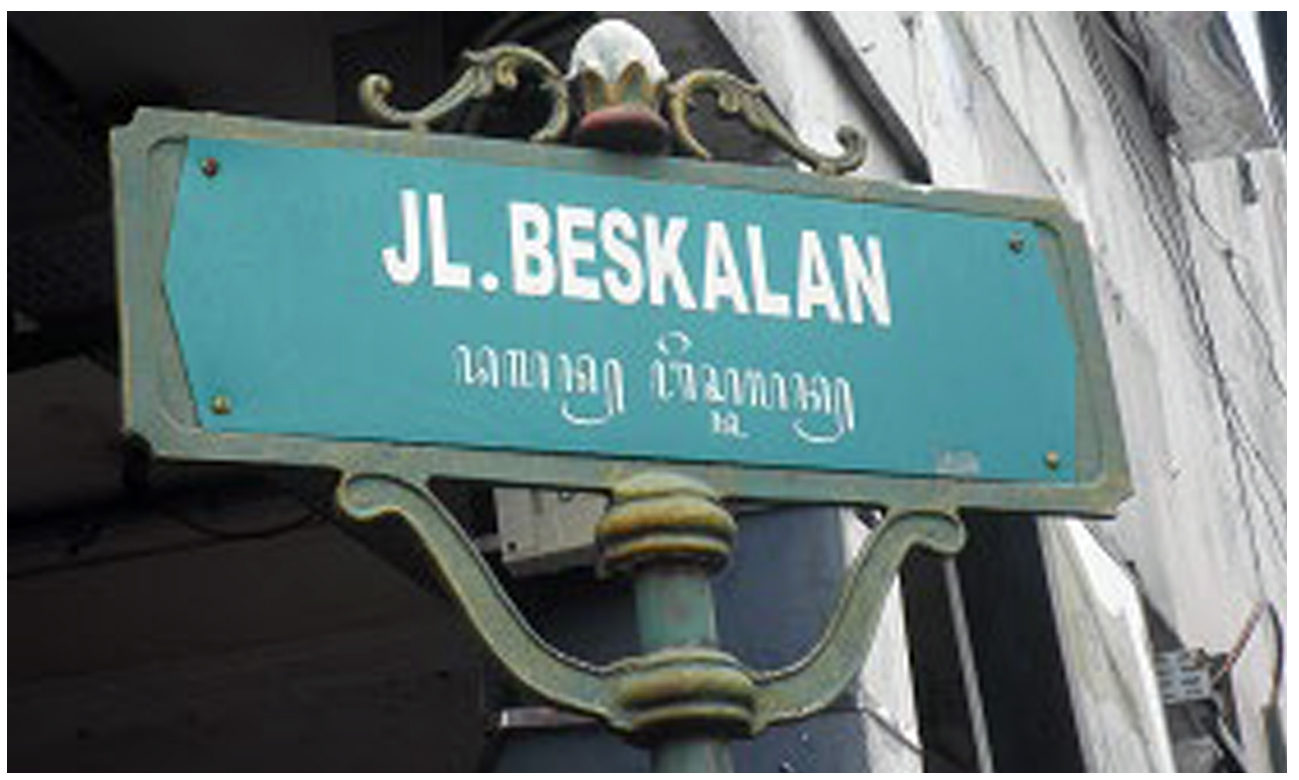

Figure 15. Sample of a sign in Latin and Javanese scripts. (Collection of authors).

\subsection{LANGUAGE PREFERENCES}

Our survey indicates a preference for both Indonesian and English on commercial, regulatory, and infrastructural signs (see Table 6). In this category, most of the respondents preferred reading signs not only in Indonesian but also in English. Only a few (10\%) thought that signs should be only in Indonesian. To be more specific, in commercial establishments, more international than local tourists preferred mixed English-Indonesian signs (75\% internationals compared to $50 \%$ locals). The same is true of infrastructural signs $(70 \%$ internationals and 50\% locals). No such discrepancy was attested for regulatory signs. These findings support the claim that international tourists require written information in English particularly in the domains of directions and public transportation. The respondents' language preferences are in line 
with those in Mallorca (Bruyèl-Olmedo and Juan-Garau 2009): more signs in English as most of them speak English. Finally, around 30 percent of the respondents preferred signs in Indonesian, English, or Javanese. Interestingly, more international than local tourists wanted to read infrastructural signs not only in Indonesian and English, but also in Javanese.

\begin{tabular}{lllllll}
\hline Type of sign & \multicolumn{9}{l}{ Language preference } \\
\cline { 2 - 7 } & Only Ind & \multicolumn{2}{l}{ Ind and Eng } & \multicolumn{2}{l}{ Ind, Eng, and Jav } \\
& no. & $\%$ & no. & $\%$ & no. & \% \\
\hline Commercial & $\mathbf{4}$ & $\mathbf{1 0} \%$ & $\mathbf{2 5}$ & $\mathbf{6 3} \%$ & $\mathbf{1 1}$ & $\mathbf{2 7 \%}$ \\
Local tourists & 3 & $15 \%$ & 10 & $50 \%$ & 7 & $35 \%$ \\
International tourists & 1 & $5 \%$ & 15 & $75 \%$ & 4 & $20 \%$ \\
Regulatory & $\mathbf{4}$ & $\mathbf{1 0} \%$ & $\mathbf{2 4}$ & $\mathbf{6 0 \%}$ & $\mathbf{1 2}$ & $\mathbf{3 0 \%}$ \\
Local tourists & 3 & $15 \%$ & 10 & $50 \%$ & 7 & $35 \%$ \\
International tourists & 1 & $3 \%$ & 14 & $47 \%$ & 15 & $50 \%$ \\
Infrastructure & $\mathbf{4}$ & $\mathbf{1 0} \%$ & $\mathbf{2 4}$ & $\mathbf{6 0} \%$ & $\mathbf{1 2}$ & $\mathbf{3 0 \%}$ \\
Local tourists & 3 & $15 \%$ & 10 & $50 \%$ & 7 & $35 \%$ \\
International tourists & 1 & $5 \%$ & 14 & $70 \%$ & 5 & $25 \%$ \\
\hline
\end{tabular}

Table 6. Survey of language preferences in Malioboro. (Collection of authors).

In the context of touristic locations as "spaces of movement, destination, experience, memory and representation [...]" (S. Wearing et al. 2010: 10), the expectations of foreign respondents about learning more about the local culture, including language, are unsurprising. They show that present-day tourism is not just an object in itself, but a means of self-fulfilment. Nowadays, tourists are willing to invest in visiting places far from their homes and do so regularly. They no longer simply pay a visit to a resort and take pictures; they want to take "something" home: memorable moments and great experiences, involving their senses, feelings, and opinions manifested through their interactions with the locality, people, culture, and language of the destinations (Wearing et al. 2010). Tourists attribute meanings to these interactions with places and to many people these have become a primary need.

\subsection{SIGN INFORMATIVENESS, CLARITY, AND VISIBILITY}

Our data reveal that, in general, all three types of public signs in Malioboro have been found to be informative in that they contain the information needed by their readers (see Table 7). The degree of the informativeness is high (above $90 \%$ ). However, the degree of clarity is much lower (13\% for commercial, $10 \%$ for regulatory, and $25 \%$ for infrastructure). In other words, despite the informativeness of the signs, they did not generate those consulting them clear messages. Finally, the rate of the signs visibility is around 70 percent for all types of signs, both to local and international tourists. Some respondents indicated that a number of signs were difficult to see. In addition, some signs index to objects not shown on the signs. 


\begin{tabular}{|c|c|c|c|c|c|c|}
\hline \multirow[t]{2}{*}{ Type of sign } & \multicolumn{2}{|c|}{ Informative } & \multicolumn{2}{|l|}{ Clear } & \multicolumn{2}{|l|}{ Visible } \\
\hline & $\begin{array}{l}\text { Yes } \\
\text { (no.,\%) }\end{array}$ & $\begin{array}{l}\text { No } \\
\text { (no.,\%) }\end{array}$ & $\begin{array}{l}\text { Yes } \\
\text { (no.,\%) }\end{array}$ & $\begin{array}{l}\text { No } \\
\text { (no.,\%) }\end{array}$ & $\begin{array}{l}\text { Yes } \\
\text { (no.,\%) }\end{array}$ & $\begin{array}{l}\text { No } \\
\text { (no.,\%) }\end{array}$ \\
\hline Commercial & $3795 \%$ & $25 \%$ & $5 \quad 13 \%$ & $3487 \%$ & $3179 \%$ & $821 \%$ \\
\hline Local tourists & $19100 \%$ & $00 \%$ & $211 \%$ & $1789 \%$ & $1579 \%$ & $421 \%$ \\
\hline International tourists & $1890 \%$ & $210 \%$ & $315 \%$ & $1785 \%$ & $1680 \%$ & $420 \%$ \\
\hline Regulatory & $3795 \%$ & $25 \%$ & $4 \quad 10 \%$ & $3590 \%$ & $3178 \%$ & $923 \%$ \\
\hline Local tourists & $1895 \%$ & $15 \%$ & $211 \%$ & $1789 \%$ & $1680 \%$ & $420 \%$ \\
\hline International tourists & $1995 \%$ & $15 \%$ & $210 \%$ & $1890 \%$ & $1575 \%$ & $525 \%$ \\
\hline Infrastructure & $3897 \%$ & $13 \%$ & $1025 \%$ & $3075 \%$ & $3178 \%$ & $923 \%$ \\
\hline Local tourists & $19100 \%$ & $00 \%$ & $5 \quad 25 \%$ & $1575 \%$ & $1470 \%$ & $630 \%$ \\
\hline International tourists & $1995 \%$ & $15 \%$ & $5 \quad 25 \%$ & $1575 \%$ & $1785 \%$ & $315 \%$ \\
\hline
\end{tabular}

Table 7. Survey on the informativeness of signs in Malioboro.

Malioboro abounds in signs. Signs pertaining to established shops are punctuated by those belonging to street vendors (kaki lima). Regulations dictating their placement and quantity are conspicuous by their absence. Commercial and non-commercial signs on the eastern side of the pavement overlap with the goods on offer. It is not surprising that visitors find it hard to locate and read signs they need. The survey results, particularly with regard to the clarity and visibility of regulatory and infrastructural signs, need urgent attention from the authorities. The placement and content of such signs should be prioritized in efforts to develop Malioboro into a more comfortable tourist destination. Several respondents believe that the authorities need to make sensible plans for this area. Previous cases have shown how government involvement in planning and executing the necessary regulations can be applied to public signs for tourists (Ikuta 2010).

\section{CONCLUding REMARKS}

The dominance of Indonesian in the LL of Malioboro, on both commercial and non-commercial signs, reflects language policy implementation on the grassroots level. Nevertheless, using Indonesian as the lingua franca of public signs can also be viewed as a means of connecting the visitors, sellers, buyers, tourists, and students who come to this destination from different regions and with different purposes. However, the predominance of Indonesian also suggests an exclusiveness in the face of not only local but also overseas tourists in this popular street. Clearly, the readership chiefly targeted consists of Indonesian speakers. Multilingualism hardly gets a look in in the LL of Malioboro, even though it is a student and tourist destination; Yogyakarta welcomes people from many regions of Indonesia, including Ambon, Atambua, Bandung, Jakarta, Makassar, Medan, Manokwari, and Samarinda.

We feel that the presence of Javanese, both in its original script and in romanized form, should be highly appreciated. The language serves a symbolic function, marking the identity of Malioboro as cultural heritage. 
It has both informative and symbolic functions, designed not only to attract people's attention, but also to help preserve the locality. This is in line with the expectations of foreign tourists: to be able to read signs which contain English and the ready visibility of public signs. These points require urgent serious attention from the local authorities.

Further research on Nusantara LLs could, for instance, focus on proper names, multilingualism and its (lack of) representations, trans-languaging in commercial advertisement, and the semiotic landscape of Malioboro and other sites as hubs of both business and culture. We do hope that this article will play a role in future comparisons between Malioboro and the linguistic landscapes of various other shopping streets, in Indonesia and beyond.

\section{REFERENCES}

Ashley, C.D., A. Lehr, and H. Wilde. 2007. The role of the tourism sector in expanding economic opportunity. Cambridge, MA: The Fellows of Harvard College, Overseas Development Institute, International Business Leaders Forum.

Backhaus, P. 2006. "Multilingualism in Tokyo; A look into the linguistic landscape", in: Durk Gorter (ed.), Linguistic landscape; A new approach to multilingualism, pp. 52-66. Clevedon: Multilingual Matters.

Ben-Rafael, E., E. Shohamy, M.H. Amara, and N. Trumper-Hecht. 2006. "Linguistic landscape as symbolic construction of the public space; The case of Israel", in: Durk Gorter (ed.), Linguistic landscape; A new approach to multilingualism, pp. 7-30. Clevedon: Multilingual Matters.

Bruyèl-Olmedo, A. and M. Juan-Garau. 2009. "English as a lingua franca in the linguistic landscape of the multilingual resort of $S^{\prime}$ Arenal in Mallorca", International Journal of Multilingualism Vol. 6 No. 4 (January): 386-411.

Cenoz, J. and D. Gorter. 2006. "Linguistic landscape and minority languages", in: Durk Gorter (ed.), Linguistic landscape; A new approach to multilingualism, pp. 67-80. Clevedon: Multilingual Matters.

Central Bureau of Statistics. 2015. “Home; Tourism; Revenue from foreign tourists based on country of origin (in million US\$), 2000-2014". [Retrieved from: https://www.bps.go.id/linkTabelStatis/view/id/1392, accessed on 17-07-2017.]

Central Bureau of Statistics Special Region of Yogyakarta Province. 2014. The statistics of special region of Yogyakarta 2014. Yogyakarta: Central Bureau of Statistics Special Region of Yogyakarta Province.

Coluzzi, P. 2012. "The linguistic landscape of Brunei", Southeast Asia; A Multidisciplinary Journal Vol. 12: 1-16.

Da Conceição Savio, E. 2015. Studi sosiolinguistik bahasa Fataluku di Lautém. PhD thesis, Tilburg University.

Da Silva, A.M. 2014. "Upon the prevalence of English on billboard advertisements; Analyzing the role of English in Indonesian contexts", TEFLIN Journal Vol. 25 No. 1 (January): 33-61. 
Da Silva, A.M. 2016. On English prevalence and characteristics; A case study of inguistic landscape along the main streets of five administrative towns in Jakarta. PhD thesis, Atma Jaya Catholic University of Indonesia.

Da Silva, A.M. 2017. "Exploring the language choice of the non-commercial signs in Jakarta”, Indonesian Journal of Applied Linguistics Vol. 7 No. 2 (September): 467-475.

Da Silva, A.M. and D.A. Kwary. In progress. On identity construction; A case study of the linguistic landscape in Gambir train station, Jakarta, Indonesia.

Department of Education, Youth and Sports of Special Region of Yogyakarta. 2015. "Brief history of Special Region of Yogyakarta". [Retrieved from: http:/ / www.pendidikan-diy.go.id/dinas_v4/?view=v_gallery\&id_ folder $=18 \& \mathrm{~h}=1$; accessed on 17-07-2017.]

Edelman, L. 2010. Linguistic landscape in the Netherlands; A study of multilingualism in Amsterdam and Friesland. Utrecht: LOT.

Huebner, T. 2006. “Bangkok's linguistic landscapes; Environmental print, codemixing, and language change", in: Durk Gorter (ed.), Linguistic landscape; A new approach to multilingualism, pp. 31-51. Clevedon: Multilingual Matters.

Ikuta, A. 2010. Visitor sign; Comparison of visitor signs in Helsinki and Kyoto. Vaasa: Vaasan Ammattikorkeakoulu-Vasa Yrkeshogsköla.

Kim, H.J., M.-H. Chen, and S. Jang. 2006. “Tourism expansion and economic developmnent; The case of Taiwan", Tourism Management Vol. 27 No. 5 (October): 925-933.

Lanza, E. and H. Woldemariam. 2013. "Indexing modernity; English and branding in the linguistic landscape of Addis Ababa", International Journal of Bilingualism Vol. 18 No. 5 (May): 491-506.

Lawrence, B. 2012. "The Korean English linguistic landscape”, World Englishes Vol. 31 No. 1 (February): 70-92.

Moriarty, M. 2014. "Contesting language ideologies in the linguistic landscape of an Irish town", International Journal of Bilingualism Vol. 18 No. 5 (October): 464-477. [DOI:10.1177/1367006913484209.]

Nikolaou, Alexander. 2017 "Mapping the linguistic landscape of Athens; The case of shop signs", International Journal of Multilingualism Vol. 14 No. 2 (March): 160-182.

Papen, U. 2012. “Commercial discourses, gentrification, and citizens' protest; The linguistic landscape of Prenzlauer Berg", Journal of Sociolinguistics Vol. 16 No. 1 (February): 56-80.

Provincial Government of Special Region of Yogyakarta. 2017. “Application of Provincial Government of Special Region of Yogyakarta". [Retrieved from: https:/ /jogjaprov.go.id/; accessed on 23-11-2017.]

Ruzaite, J. 2017. "The linguistic landscape of tourism; Multilingual signs in Lithuanian and Polish resorts", ESUKA-JEFUL Vol. 8 No. 1 (March): 197-220.

Salim, M.A., N.A. Ibrahim, and H. Hassan. 2012. "Language for tourism; A review of literature", Procedia-Social and Behavioral Sciences Vol. 66 (December): 136-143. 
Sartono. 2018. "Penggunaan bahasa di ruang publik kota Surakarta; Kajian lanskap linguistik". MA thesis, University of Indonesia.

Sayer, P. 2010. "Using the linguistic landscape as a pedagogic al resource", ELT Journal Vol. 64 No.1 (April): 143-154.

Scollon, R. and S.W. Scollon. 2003. Discourses in place; Language in the material world. London: Routledge.

Taylor-Leech, K.J. 2012. “Language choice as an index of identity; Linguistic landscape in Dili, Timor-Leste". International Journal of Multilingualism Vol. 9 No. 1 (February): 15-34.

The Ministry of Secretarial Affairs. 2017. "President Jokowi; Our tourism sector is more than other countries". [Retrieved from: http:/ / www.setneg. go.id/ index.php?option=com_content\&task=view\&id=8726; accessed on 23-11-2017.]

The Ministry of Tourism. 2017. "Statistic of overseas tourist". [Retrieved from: http:/ / www.kemenpar.go.id/asp/detil.asp?c=110\&id=3139; accessed on 23-11-2017.]

Torkington, K. 2009. "Exploring the linguistic landscape; The case of the 'Golden Triangle' in the Algarve, Portugal'. [Paper, Lancaster University Postgraduate Conference in Linguistic and Language Teaching, Lancaster, 3 July.]

Wearing, S., D. Stevenson, and T. Young. 2010. Tourist cultures; Identity, place, and the traveller. London: Sage.

World Tourism Organization. 2001. Tourism signs and symbols; A status report and guidebook. Madrid: World Tourism Organization.

Yannuar, N. 2018. “Wòlak-waliké jaman; Exploring contemporary Walikan in public space", Wacana, Journal of the Humanities of Indonesia Vol 19 No. 1: 100-121.

\begin{abstract}
ABOUT THE AUTHORS
ANNA MARIETTA DA SILVA received her Dr in English Applied Linguistics in 2016 from the Atma Jaya Catholic University of Indonesia (AJCUI). Presently, she is a faculty member at the Department of English Applied Linguistics, Faculty of Education and Languages of the AJCUI. She has published research articles on Sociolinguistics, Pragmatics, and English Language Teaching as well as a book on research methods. Her research interests include language policy, globalization of English, and English language learning. Anna Marietta da Silva can be reached at: anna.silva@atmajaya.ac.id.
\end{abstract}

YASSIR NASANIUS TJUNG received his PhD from the University of Delaware in 2006. Currently, he is the Chair of the Master's Program at the Department of English Applied Linguistics, Faculty of Education and Languages of the Atma Jaya Catholic University of Indonesia. He has published research articles on Syntax and Generative Grammar in reputable international journals. His research interests include Generative Grammar, Syntax, Psycholinguistics, Semantics, and Language Acquisition. Yassir Nasanius Tjung can be reached at: yns@atmajaya. ac.id. 
SRI HAPSARI WIJAYANTI received her M.Hum. in Linguistics from the University of Indonesia. She is a lecturer at the Faculty of Economics of the Atma Jaya Catholic University of Indonesia and a teacher of Indonesian for Foreigners. She has published research articles on language use in society and business communication. She has also published books on writing and pedagogy: Menulis esai yang efektif (2011, Surakarta: Pelangi Press), Bahasa Indonesia; Menulis dan menyajikan karya ilmiah (2013, Jakarta: Raja Grafindo Persada), and Kunci guru profesional (co-author with Clara Ika Sari Budhayanti, 2019, Yogyakarta: Media Akademi). Sri Hapsari Wijayanti can be reached at: sri.hapsari@atmajaya.ac.id.

CHISTIANY SUWARTONO received her PhD from the Radboud University of Nijmegen, the Netherlands in 2018. She has joined the Faculty of Psychology of Atma Jaya Catholic University of Indonesia since 2007. She specializes in the field of Psychology and Psychometrics. In 2019 she received the Sarlito W. Sarwono Award of the Nusantara Psychological Science Consortium. Currently, she is a post-doctoral trainee at the University of Illinois at Chicago in Advanced Research Methods and Translational Science. Her research focuses on human interactions and how to improve human health and well-being in Indonesia. Christiany Suwartono can be reached at: christiany.suwartono@atmajaya.ac.id. 